\title{
Evaluation of Delayed Puberty of Patients with Beta Thalassemia Major in -Diyala Governorate
}

\section{Alaa A Mahmud (BSc) $)^{1}$, Ali M Al-Gharawi $(\mathrm{PhD})^{2}$ and Falah M Mustafa $(\mathrm{PhD})^{3}$}

\begin{abstract}
Background: The absence of secondary sexual characteristics are known complications in patients with beta thalassemia major.

Objective: Evaluation the effects of frequent blood transfusions on puberty in patients afflicted with beta thalassemia ( $\beta$-thal) major.

Patients and Methods: Eighty patients with beta thalassemia major were categorized into two groups, 51 male and 29 female, and 40 normal individuals were chosen as a control group. The concentrations of the luteinizing hormone(LH), follicle stimulating hormone(FSH) in both genders,Estradiol in female and testosterone in male were evaluated in the sera of patients and controls by ELISA method.

Results: The mean concentrations of serum FSH ,LH, estradiol in female ,and testosterone in male showed highly significant decrease in patients with beta thalassemia major in comparison with control group. Hypogonadotropic hypogonadism was reported in $67.5 \%$ of all $\beta$ thalassemia patients $(70.6 \%$ of male and $62.1 \%$ of female ).

Conclusion: Delayed puberty is caused by the effect of excess iron on the anterior lobe of pituitary gland.

Key words: Delayed puberty ,Blood transfusion, Hypogonadotropic hypogonadism.

Corresponding Author: alaa.alzuhary@yahoo.com

Received: $5^{\text {th }}$ August 2018

Accepted: $16^{\text {th }}$ September 2018

https://doi.org/10.26505/DJM

${ }^{1}$ Baqubah Teaching Hospital -Diyala - Iraq.

${ }^{2}$ Foundation of Technical Education- Section of Medical Laboratory Science Technology- College of Health and Medical Technology-Baghdad l-Iraq.

${ }^{3}$ Al-Batool Teaching Hospital for Obstetrics and Pediatrics -Diyala -Iraq.
\end{abstract}

\section{Introduction}

Beta-thalassemia ( $\beta$-thal) syndromes are grouping of inherited blood disorders characterized by reduce or missing of beta globin chain synthesis, resulting in reduced amounts of haemoglobin $) \mathrm{Hb}$ ( in the red blood cells (RBC), decrease RBC creation and anemia. The majority of thalassemias are inherited as recessive traits [1] .

Frequent blood transfusions with increased gastrointestinal iron absorption lead to an iron overload in the body [2]. Human are unable to remove the iron, and the overload iron is deposited as hemosiderin and ferritin in the liver, spleen, endocrine organs and myocardium [3] .Poor growth and manifold endocrinopathies, include hypogonadotropic hypogonadism $(\mathrm{HH})$, growth hormone deficiency, are recognized complications in beta thalassemia major (TM), and are considered the result of iron excess [4]. Failure of pubertal growth, delay or lack of sexual progress, amenorrhea, sexual 
dysfunction and infertility due to hypogonadism are well-known disorder of the hypothalamic - pituitary - gonadal axis in $\beta$-thal patients[5].

\section{Patients and Methods}

Eighty patients(51males and 29 females) with $\beta$ - thalassemia major with an age range of 14-30 years (mean $18.80 \pm 4.58$ years)for male and 13-30 years (mean17.48 \pm 4.83 ) for females were studied. Sera were collected from the patients at Baqubah Teaching Hospital - The Specialized Center of Hereditary Blood Diseases ,Baquba-Diyala.The diagnosis of $\beta$ thalassemia major was made by the consultants, considering the results of hemoglobin electrophoresis ,laboratory investigations and clinical features of the patients.

The data were collected about sex, age, ,socio-economic state, marital status, parent consanguinity, family history, medical and surgical history (e.g.splenectomy),date of diagnosis, date of first blood transfusion, period, between blood transfusions, medication history ,puberty information including questions about the presence of secondary sexual characteristics .In female ,menstruation history was reported .Forty healthy subjects(23male and 17 female) were taken as a control group for comparison. Chi-square test and T-test were used to the distinction between two independent means.

\section{Sample collection}

About 5 milliliters venous blood were obtained from all subjects(patients and controls). In thalassemic patients ,sampling was done just before the blood transfusion jIn menstruating thalassemia major female patients and controls, venous blood samples were drawn through the mid-follicular phase of the menstrual cycle (days 5-8). The blood samples were centrifuged at $3000 \mathrm{rpm}$ for 10 minutes and sera were freezed at about $20^{\circ} \mathrm{C}$ ( until examination )didn't exceed 10 weeks [6].

\section{Statistical analysis}

Basic serum biochemical parameters including, follicular stimulating hormone(FSH) ,luteinizing hormone (LH), serum estradiol in female and serum testosterone in male were assayed for patients and control groups within eight weeks by ELISA method [7].

\section{Results}

In this study fifty four $\beta$-thal patients $(67.5 \%)$ were suffering from hypogonadotropic hypogonadism, while twenty six (32.5\%)were eugonadism, Table(1). A high significant decrease ( $\mathrm{p}<$ 0.001) was seen in patients in serum follicle stimulating hormone FSH, luteinizing hormone(LH), testosterone and estradiol,when compared with healthy control, Table(2). 
Table (1): Distribution of Thalassemic Patients and Healthy Controls According to Hypogonadotropic Hypogonadism and eugonadism.

\begin{tabular}{|c|c|c|c|c|c|c|c|c|}
\hline \multirow[t]{3}{*}{ Secondary hypogonadism } & \multicolumn{4}{|c|}{ Male } & \multicolumn{4}{|c|}{ Female } \\
\hline & \multicolumn{2}{|c|}{ Thalassemia } & \multicolumn{2}{|c|}{ Control } & \multicolumn{2}{|c|}{ Thalassemia } & \multicolumn{2}{|c|}{ Control } \\
\hline & No & $\%$ & No & $\%$ & No & $\%$ & No & $\%$ \\
\hline Yes & 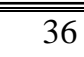 & $\overline{\overline{770.6}}$ & - & 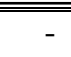 & 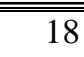 & 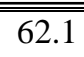 & - & 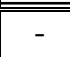 \\
\hline No & 15 & 29.4 & 23 & 100 & 11 & 37.9 & 17 & 1100 \\
\hline P value & \multicolumn{4}{|c|}{0.0001} & \multicolumn{4}{|c|}{0.0001} \\
\hline
\end{tabular}

Table (2): Mean Concentration of the hormones in the Sera of Studied Groups.

\begin{tabular}{|l||c||c|c|c|}
\hline \multicolumn{1}{|c||}{} & \multicolumn{2}{c|}{ Male } & \multicolumn{2}{c|}{ Female } \\
\cline { 2 - 5 } & Thalassemia & Control & Thalassemia & Control \\
\hline \hline LH (mIU/ml) & $2.19 \pm 1.19$ & $7.01 \pm 2.14$ & $2.98 \pm 2.77$ & $10.73 \pm 3.93$ \\
& $(0.3-5.3)$ & $(4.1-12.0)$ & $(0.2-12.0)$ & $(6.1-21.9)$ \\
& $2.78 \pm 1.94$ & $6.97 \pm 2.63$ & $3.41 \pm 1.36$ & $12.15 \pm 2.39$ \\
& $(0.3-10.5)$ & $(4.0-12.2)$ & $(1.1-6.6)$ & $(8.3-17.0)$ \\
\hline \hline FSH (mIU/ml) & $1.64 \pm 1.75$ & $3.89 \pm 1.31$ & - & - \\
& $(0.2-6.2)$ & $(1.7-6.7)$ & & \\
\hline \hline Testosterone & - & - & $14.77 \pm 20.22$ & $59.65 \pm 45.70$ \\
$(\mathrm{ng} / \mathrm{ml})$ & & & $(1.3-101.0)$ & $(21.0-185.0)$ \\
\hline Estradiol $(\mathrm{pg} / \mathrm{ml})$ & & & & \\
& & &
\end{tabular}

\section{Discussion}

Delayed puberty and hypogonadism are the most common iron- related endocrinological complications reported in almost all studies from a range of countries[8]. Primary hypogonadism is associated with low levels of testosterone /estradiol and high-normal to high levels of LH and FSH. Secondary hypogonadism(hypogonadotropichypogonad ism $\mathrm{HH}$ ) is associated with low levels of testosterone /estradiol and normal to low levels of LH and FSH[9, 10]. In the present study $70.6 \%$ of male and $62.1 \%$ of female patients with $\beta$-thal major developed hypgonadotropic hypogonadism .

The similar study was defined by Soliman et al [11], who reported that thalassaemic patients had a total absent of pubertal changes in $73 \%$ of boys plus $42 \%$ of girls with thalassemia between the ages of 13 and 21 years. De Sanctis et al[12], reported that there is a considerable percent $(30 \%)$ of patients with $\beta$-thalassemia major having hypgonadotropic hypogonadism . Kwan et $a l[13]$, have recorded that $62 \%$ of boys with $75 \%$ of girls above the age of 12 years had hypgonadotropic hypogonadism . 


\section{Conclusion}

In $\beta$-thal .major patients the majority of the studied patients were at age range of (15-19 year) for both sexes. Therefore ,early diagnosis of hypogonadism is crucial to ensure normal sexual development and puberty and avoid irreversible complications. Although therapy with Deferoxamine to treat iron overload ,the threat of secondary hypogonadism remained elevated.

\section{References}

[1]Galanello R, Origa R. "Beta-thalassemia. Orphanet", J. of Rare Diseases; 2010; vol.5:pp11.

[2]Milena R, Branka Z, Biljana S. "Thalassemia syndrome in Serbia" Haemoglobin, 2010;34:pp477-485.

[3]Taher A, Isma'eel $\mathrm{H}$, Cappellini MD. "Thalassemia intermedia: revisited" Blood Cells Mol. Dis; 2006; 37: pp12-20.

[4]Rund D, Rachmilewitz E. "Betathalassemia" N Engl J Med; 2005;353: pp1135-1146.

[5]Thein SL." Beta-thalassaemia" Baillieres Clin Haematol; 1998;11: pp91-126.

[6]Marshall, WJ.Bangert, SK." Thyroid dysfunction, clinical biochemistry: Metabolic and clinical aspects" ;2008; 2nd ed., chapter 19; P: 397.

[7]Monobind Inc. Follicle stimulating hormone (FSH) test ELISA system(user $\mathrm{s}$ manual) ;2011; 2:1-4.

[8]Eleftheriou A. About thalassemia:Medical problems associated with thalassemia and its treatment.Thala Inter Feder,Cyprus; 2007;62-70.
[9]Griffin JE, Wilson JD."Disorders of the testes.Harrison's principles of internal medicine. In:Endocrinology \& Metabolism". NewYork, NY: McGraw Hill; 2001; 15th Ed ,335:pp2143-2154.

[10]Kodaman PH, Arici A ." Intra-uterine adhesions and fertility outcome: how to optimize success?" Curr Opin Obstet Gynecol ; 2007; vol.19:pp207-214.

[11] Soliman AT, El Zalabany M, Amer M, Ansari BM." Growth and pubertal development in transfusion dependent children and adolescents with thalassaemia major and sickle cell disease: a comparative study". J Trop Pediatr, 1999; 45: pp23-30. [12] De Sanctis et al. "multicentre study on endocrine complications in thalassaemia major"Clin Endocrinol ; 1995;42:pp581-586. [13] Kwan EY, Lee AC, Li AM, Tam SC, Chan CF, Lau YL, et al. "A cross-sectional study of growth, puberty and endocrine function in patients with thalassaemia major in Hong Kong" J Paediatr Child Health ; 1995;31:pp 83-87. 